have had a National Academy of Sciences study on it. The program is now bifurcated through a number of agencies. It is not being very well run. The technology that is being used is outdated, and the groundbase system for gathering the data is, in fact, a mess, because it was created not to serve any scientific needs. It was created as pure pork for members of Congress. We created a bunch of data-gathering stations all over the country, and dumped them in the districts of chairs of appropriation subcommittees, authorization subcommittees, full committees, and so on. They all have a data-collection station. The fact is that you can make the program better and save some money, which is what we ultimately had to do with Space Station. The reason why Space Station is now getting over 300 votes when we vote in the Congress these days is because we now have a program which is sustainable. Mission to Planet Earth in its present form is not sustainable. And yet, the pork barrel raised its head in the deliberations over that program and we ended up cutting some programs with a one-time cut, but we won't be able to do that again next year. Then we will be right back in the soup again. I think that could be detrimental to the overall science effort.

\section{What's Ahead}

I described the seven-year budget as being a very real issue with all of us. I believe that the seven-year budget is something which is absolutely mandatory if we are ever going to get it to balance. The seven-year budget is also going to be the fundamental issue in setting priori-

\begin{tabular}{|c|c|}
\hline \multicolumn{2}{|c|}{ Advertisers in This Issue } \\
\hline Academic Press, Inc. & 85 \\
\hline gital & \\
\hline $\begin{array}{l}\text { High V } \\
\text { Europa }\end{array}$ & ont cover \\
\hline $\begin{array}{l}\text { Huntington } \\
\text { Laboratories }\end{array}$ & utside back cover \\
\hline MDC Vacuum Products Corf & 15 \\
\hline National Electrostatics Corp. & 10 \\
\hline New Focus, Inc. & inside back cover \\
\hline Tencor Instruments & g \\
\hline Virginia Semiconductor, Inc. & 11 \\
\hline oltaix, Inc. & 2 \\
\hline
\end{tabular}

For free information about the products and sevices offered in this issue, fill out and mail the Reader Senvice Card, or FAX it to (312) 922-3165 ties. That is a policy debate that you had better be very interested in because science and technology will suffer if we can't do something to rein in entitlement and welfare programs. If we cannot find some way to hold the line on those programs we are simply not going to be able to find the money that we need for discre-

\section{Zeroing out the Commerce Department will mean that we will have an independent mission- oriented science agency that combines NOAA and NIST.}

tionary programs. And science and technology are discretionary programs.

We need the ability for a new knowledge-based economy with United States leadership. Now we can't get there if we don't do something about this massive debt load that we have been carrying. The fact is interest and debt in all of those kinds of things are eating alive the seed corn of what we need to invest in the future. I carry along with me, and the Speaker has been doing the same thing recently, my vacuum tube. Most of you are familiar with that. You probably haven't used them in a long time. Your laboratories probably don't have many of them around any longer. Well I shouldn't say you haven't used them in a long time, because you did. If you flew in here, you used them, because the world's largest supply of vacuum tubes goes to the FAA [Federal Aviation Administration] these days. It still runs their technology on vacuum tubes. Now [I also have] a pentium chip. As most of you know, [a pentium chip is the equivalent of] about 2.2 million [vacuum tubes]. The Congress, just within the last few weeks, got around to installing technology using [modern] technology. And the government is still well behind that curve. That says something about the [process]. We need to have a [process] that allows us to go very quickly from the development of knowledge to the creation of technology, to the consumer marketplace. Government, for the most part, is not a help in that process; it is a hindrance. It gets in the way in many ways with regulation, with taxation, and with litigation. You name it. Now some of that is very necessary and is very good. But the fact is there is a sorting-out process that has to take place and some of what we are trying to do in the budget debate is decide how that sorting-out process is going to allow us to become a part of a world-based, knowledge-based economy.

The great British statesman Benjamin Disraeli one time said that, "Men and nations move from bondage to faith, from faith to courage, from courage to freedom, from freedom to abundance, from abundance to complacency, from complacency to dependency, and from dependency back to bondage." The interesting thing about that historic continuum is that each generation really gets to choose. I think we are in a period of time right now where we are making fundamental choices. I think that this is a period of time when we can, in fact, choose the no-risk, big-government solution to everything; where we can choose to become more and more complacent about what the future looks like; where we can choose to become dependent upon government to make the decisions for us, and I think that dooms us in very terrible ways in the future. But I also think it is a time when there is a burgeoning new economy, when there are choices that can be made that will put us on the course of courage and freedom, and, I think, abundance.

In large part, what we are doing in trying to develop a new science agenda is to assure that we have the freedom to act so that we can produce the abundance of the future. What it is going to take to get there is a little bit of courage. That is what I hope this nation will demonstrate that it has in the weeks and months ahead.

Robert S. Walker has been the U.S. congressional representative of Lancaster and Chester counties in Pennsyloania since 1977. He chairs the Committee on Science in the U.S. House of Representatives. Its jurisdiction includes space and aeronautics, basic research, energy and environmental research and development, as well as technology. In addition, he is vice-chair of the Committee on Budget. which determines the budget for the federal government. Walker received a master's degree in political science from the University of Delaware in 1968.

\section{SEND LETTERS TO THE EDITOR TO}

Editor, MRS Bulletin, Materials Research Society, 9800 McKnight Road, Pittsburgh, PA 15237-6006 fax 412-367-4373; e-mail bulletin@mrs.org. 